Copyright (C) 2021 by Cherkas Global University

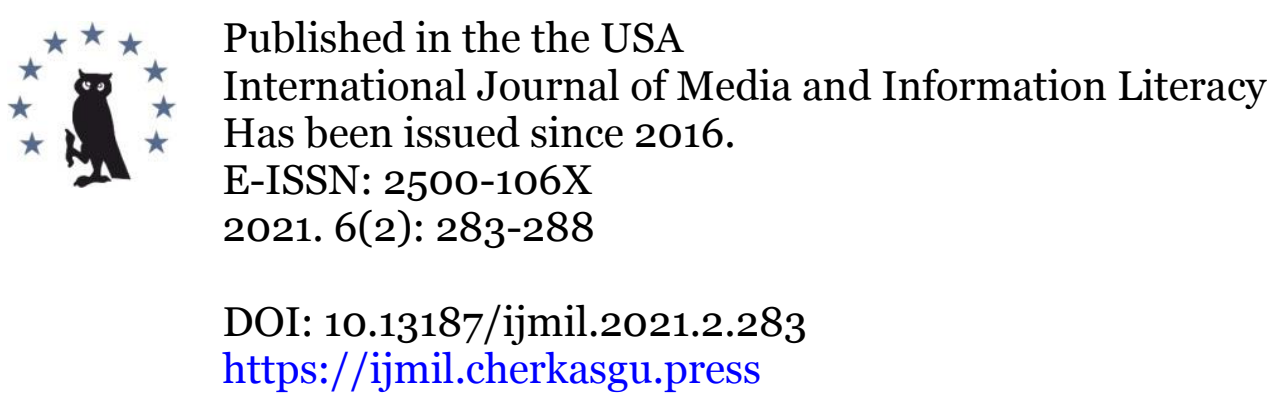

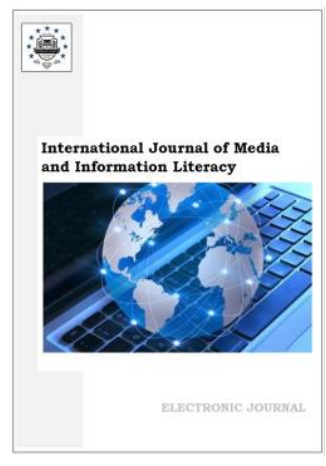

\title{
Methodology, Technology and Practice of Organizing Media Education Seminars and Workshops for Teachers on Promoting Interethnic Tolerance in the University Student Community
}

Irina Chelysheva ${ }^{\text {a , * }}$, Galina Mikhaleva ${ }^{\text {a }}$

${ }^{a}$ Rostov State University of Economics, Russian Federation

\begin{abstract}
The relevance of improving the methodological training of present-day university teaching staff is due to the dynamic changes taking place in the system of higher education. The article presents the experience of conducting scientific and methodological seminars and workshops for the pedagogical community. The purpose of the seminars for teachers on promoting university students' interethnic tolerance by means of media education is to familiarize teachers with the leading methods, technologies and practical techniques of media pedagogy based on analysing media texts of different types and genres in the context of developing the culture of interethnic communication, constructive dialogue of university students in the media sphere. The authors describe the methodological and organizational aspects for teachers to use in their further professional activities in the course of integrating media education into social sciences and humanities.
\end{abstract}

Keywords: media, media education, interethnic tolerance, university students, seminars, workshops, teachers.

\section{Introduction}

Among the risks associated with digitalization and mediatization of modern society, media manipulation, "hate speech", xenophobia, and fake information that incite interethnic enmity are being highlighted nowadays. These risks may pose a particular threat to the younger generation whose interests and leisure activities are increasingly linked to social networks communication, the blogosphere and intense involvement in various media-related activities.

The "Strategy for the development of education in the Russian Federation for the period up to 2025" indicates that the socio-cultural and civic education of modern youth is directly related to promoting a culture of interethnic communication, the development of a respectful attitude of the younger generation to the national dignity of people as well as "the formation of a stable system of moral and meaningful attitudes of the individual allowing to resist the ideology of extremism, nationalism, xenophobia, corruption, discrimination on social, religious, racial, national grounds and other negative social phenomena" (Strategy..., 2015). This strategy actualizes the issues of fostering interethnic tolerance and dialogue of cultures among young people.

When education is aimed at promoting interethnic tolerance among university students, it is necessary not only to teach the younger generation, but also to purposefully prepare teachers for this activity. At the same time, it is important for teachers not only to be aware of media education techniques and methods, but also to know how to integrate them into various academic subjects

\footnotetext{
${ }^{*}$ Corresponding author

E-mail addresses: ivchelysheva@yandex.ru (I. Chelysheva)
} 
and creatively apply the studied material in classrooms. To this end, in the 2019 to 2020 and 2020 to 2021 academic years we organized training seminars and master classes at the Rostov State University of Economics in which teachers of various academic subjects took part (Chelysheva, 2020; Mikhaleva, 2020).

We will attempt to summarize the experience of these seminars and workshops, present media education methods and technologies for increasing interethnic tolerance among university students in this article.

\section{Materials and methods}

The main material for this article is practical guidelines of seminars and master classes for teachers aimed at promoting interethnic tolerance in the university student community by integrating media education; methodological tools for media education; technologies and methods of conducting practical classes with elements of media education contributing to fostering interethnic tolerance.

The practical approaches presented in the article are based on the methodology for students' performing literary activities, drama and role-play, visual and imitation activities on the material of media culture focused on the key concepts of media education: media agencies, media categories, media language, media technologies, media representations, media audiences, etc.

\section{Discussion}

According to contemporary media education studies approaches (Akhmedzyanova, 2011; Bazalgette, 1992; Buckingham, 1993, 2014; Chelysheva, Mikhaleva, 2019, 2020; Fedorov, 2007, 2015; Fedorov et al., 2020; Fedorov, Levitskaya, 2020; 2021; Gáliková Tolnaiová, 2021; Halloran, 1998; Kačinová, 2019; Khilko, 2013; Levitskaya, Fedorov, 2021; Masterman, 1996; Ramasubramanian, 2007, 2011; Rubtsova, 2013; Silverblatt, 2001; Vinichenko, 2011, 2017; Weber, 2018; Worsnop, 2004; Vrabec, Bôtošová, 2020; Zhmyrova, Monastyrskiy, 2012), media education plays an increasingly important role in the process of overcoming and preventing the risks of interethnic intolerance. It implies developing a culture of communication with media production including critical thinking and analytical skills. Unfortunately, modern universities do not actively use the potential of media pedagogy and they rarely integrate media education methods when teaching young people. Taking into account the possibilities of media education in enhancing the creative potential and upbringing the moral qualities of the individual, the goals associated with applying media education for promoting university students' interethnic tolerance are actualized in the contemporary sociocultural situation.

The integration of media education into academic subjects of the humanities and social sciences related to the study of history, psychology, pedagogy, sociology of culture and others, can play an important role in this process. We conducted a number of training seminars and master classes for teachers within the research project "Issues of Student Youth Interethnic Tolerance Reflected in Russian and English-Language Media Education of the Post-Soviet Period (19922020)" devoted to this problem.

\section{Results}

The purpose of these teacher training seminars and workshops was to acquaint teachers with the leading Russian and foreign methods, technologies and practical techniques of media pedagogy (Buckingham, 1993, 2014; Chelysheva, Mikhaleva, 2019, 2020; Fedorov, 2007, 2015; Fedorov, Levitskaya, 2020; Gáliková Tolnaiová, 2021; Kačinová, 2019; Masterman, 1996; Silverblatt, 2001; Worsnop, 2004; Vrabec, Bôtošová, 2020 and others) based on critical analysing media texts of different types and genres in the context of promoting the culture of interethnic communication, a constructive dialogue of students in the media sphere.

In particular, the teachers were offered the following topics during the seminars:

1. Possibilities of integrating media education into the academic subjects of the humanities and social sciences.

2. Interethnic tolerance as a complex quality of a student's personality and the potential of media education.

3. Media education as a means of teaching interethnic tolerance to university students: methods and technologies. 
4. Media education based on the material of cinema, television, photography, advertising: the practice of promoting interethnic tolerance among university students.

The structure of the seminars consisted of the theoretical, methodological and practical blocks. The theoretical block was devoted to studying and analysing the materials on the topic of interethnic tolerance and media education. The methodological block was devoted to familiarizing the audience with the methodological and teaching tools of integrated media education, forms and methods of media education to use in lectures and practical classes with university students in order to foster their interethnic tolerance. The practical block of seminars was aimed at students' performing creative tasks of various types for the audience to have the opportunity to immerse themselves in the creative atmosphere of the media education lesson, test and choose the most optimal techniques and technologies for further work based on the key concepts of media education: media agencies, media categories, media language, media technologies, media representations, media audiences, etc.

Working with the key concepts of media education can take many different forms. This can be a game exercise to study the possible success of a particular media text; competition for the best mini-script of social advertising on the topic of interethnic relations; a theatrical sketch that conveys the process of creating a feature film about the interethnic dialogue; selection of musical accompaniment for showing a series of photographs; creating a blog or a chat on the topic of interethnic relations; development of pedagogical situations that demonstrate different models of behaviour in international teams which can be used to illustrate the topic of an article in a magazine, etc.

The analysis of media texts based on the material of feature and documentary films, the press, advertising, photographic art, television and other media production is an important factor in enhancing the audience's interest in the issues under consideration when training teachers.

The study and discussion of media texts of different types and genres on the topic of interethnic tolerance was carried out during the seminars and master classes; the methods of brainstorming, open discussions, reviews, essays, analytical work with media critical materials were also actively used.

For example, in the course of an open discussion, the audience was asked to identify the most pressing challenges associated with the risks of the modern media space in the context of intercultural and interethnic dialogue. Among them, the teachers identified a decrease in the socalled "threshold of tolerance" which is characteristic of some media production.

Indeed, examples of negative attitudes towards representatives of other ethnic groups can often be seen in advertisements, articles in the press where "hate speech" is used, in some episodes of feature films, etc. That is why, it is so important to develop analytical skills and critical understanding of current events reflected in media texts, the ability to distinguish facts from the so-called "fakes" often found on social networks and blogs when working with media texts.

It seems to us that in order to familiarize teachers with the techniques and technologies for developing analytical skills, one of the optimal forms of work is the study of critical material about media production: reviews, articles, blogs, etc. Discussing and analysing both professional and amateur texts will allow teachers to get a deeper understanding of interethnic relations. At the next stage, it is possible to offer the audience to prepare their own media critical materials which can subsequently be analysed with university students in the course of studying some academic topic in a particular academic subject. This type of activity could become of good help for teachers preparing students for independent activities focused on media material.

Preparation for conducting a discussion at an integrated media education lesson may include a series of supporting questions for the upcoming discussion; search and classification of illustrations (frames from feature films and documentaries, photographs, advertisements and other media texts) to organize a subsequent discussion with students during a lecture or practical lesson. In our opinion, such preparatory work for the upcoming classes arouses great interest of teachers as it allows them to expand the arsenal of didactic materials and find new areas of application for media education techniques within the subject taught.

The teachers got interested in various forms and methods of organizing media education classes during the seminars. They had the opportunity to get acquainted with the algorithm for planning media projects; the main stages of arranging competitions for the best media text on the topic of interethnic tolerance; the specifics of organizing theatrical and creative work, games and role-play with media texts in the classroom; the analysis of media texts of various types and genres, etc. 


\section{Conclusion}

So, the training seminars and master classes for the pedagogical community were aimed at acquainting the teachers with the media education potential in the context of promoting university students' interethnic tolerance: expanding horizons, developing creative and communicative abilities, developing critical thinking.

During the seminars and master classes, a whole range of objectives related to fostering university students' interethnic tolerance, moral and civic education focused on media texts of various types and genres were solved:

- to form students' conscious rejection of the ideology of racial, national, interethnic, interfaith intolerance and extremism through the critical analysis of media texts;

- to destroy social prejudices and ethnic stereotypes in the student environment;

- to teach young people to distinguish between various methods of media manipulation and propaganda of interethnic intolerance in mass media when analysing media texts;

- to expand the cultural, historical and social experience, ethnocultural horizons of the student audience;

- to encourage active civic engagement in young people;

- to develop a positive national identity and a sense of patriotism among students;

- to involve young people in socially significant activities in order to form their culture of interethnic and interpersonal interaction.

\section{Acknowledgements}

This research is funded by the grant of the Russian Foundation for Basic Research (RFBR, project No. 19-013-00030) at the Rostov State University of Economics. Project theme: "Issues of Student Youth Interethnic Tolerance Reflected in Russian and English-Language Media Education of the Post-Soviet Period (1992-2020)". Head of the project is I.V. Chelysheva.

\section{References}

Akhmedzyanova, 2011 - Akhmedzyanova, A.E. (2011). Aktualizacija jempatii lichnosti sredstvami kinotreninga [Personal empathy actualization by means of film training]. PhD. Dis. Moscow. [in Russian]

Bazalgette, 1992 - Bazalgette, C. (1992). Key Aspects of Media Education. In: Alvarado, M., Boyod-Barrett O. (eds.). Media Education: An Introduction. London: BFI Publishing: 198-205.

Buckingham, 1993 - Buckingham, D. (1993). Children Talking Television. The Making of Television Literacy. London: Routledge. 338 p.

Buckingham, 2014 - Buckingham, D. (2014). Developing media literacy. Concepts, processes, and practices. London: English and Media Centre.

Chelysheva, 2020 - Chelysheva, I.V. (2020). Opyt organizacii cikla master-klassov dlja pedagogov po razvitiju mezhjetnicheskoj tolerantnosti molodezhi sredstvami mediaobrazovanija [Experience of organizing master classes on the development of interethnic tolerance of youth with the help of media education]. Crede Experto. 2(25). [Electronic resource]. URL: http://ce.if-mstuca.ru/ index.php/pedagogics/pers-media-hum-stud-in-media-edun/oocmkdpprmtmsm-en [in Russian]

Chelysheva, Mikhaleva, 2019 - Chelysheva, I.V., Mikhaleva, G.V. (2019). Russian and foreign approaches to media education of young people in matters relating to interethnic tolerance. Media Education. 59(3): 381-392. DOI: 10.13187/me.2019.3.381

Chelysheva, Mikhaleva, 2020 - Chelysheva I., Mikhaleva G. (2020). A model for developing university students' interethnic tolerance in the context of leading modern media education strategies in Russia and English-speaking countries. Media Education. 60(4): 581-590. DOI: $10.13187 / \mathrm{me} .2020 .4 .581$

Fedorov et al., 2020 - Fedorov, A., Chelysheva, I., Seliverstova, L., Levitskaya, A. (2020). Mass media education in Commonwealth of Independent States. Moscow.

Fedorov, 2007 - Fedorov, A. (2007). Razvitie mediakompetentnosti i kriticheskogo myshleniya studentov pedagogicheskogo vuza [Development of the media competence and critical thinking of pedagogical university students]. Moscow. [in Russian]

Fedorov, 2015 - Fedorov, A. (2015). Film criticism. Moscow: ICO "Information for All".

Fedorov, 2017 - Fedorov, A. (2017). Leviathan and Sunstroke: opinions of the Russian film critics. International Journal of Media and Information Literacy. 2(1): 9-15. DOI: 10.13187/ ijmil.2017.1.9 
Fedorov, Levitskaya, 2020 - Fedorov, A., Levitskaya, A. (2020). Typology and mechanisms of media manipulation. International Journal of Media and Information Literacy. 5(1): 69-78. DOI: 10.13187/ijmil.2020.1.69

Fedorov, Levitskaya, 2021 - Fedorov A., Levitskaya A. Theoretical model and technology of anti-Russian propaganda in internet communications of modern Ukraine within the framework of various student groups' media literacy education. Media Education. 17(3): 443-451. DOI: 10.13187/ me.2021.3.443

Gáliková Tolnaiová, 2021 - Gáliková Tolnaiová, S. (2021). On perspectives of teacher training and understanding of their digital competencies as determinants of digital education. Media Literacy and Academic Research. 4(1): 118-133.

Halloran, 1998 - Halloran, J.D. (1998). Ethnic Minorities and Television: A Study of Use, Reactions and Preferences. Gazette (Leiden, Netherlands). 60(4): 305-324. DOI: 10.1177/001654 9298060004003

Kačinová, 2019 - Kačinová, V. (2019). From a reductionist to a holistic model of digital competence and media education. Communication Today. 10(2): 16-27.

Khilko, 2001 - Khilko, N.F. (2001). Formirovanie jetnokul'turnoj identichnosti v processe integracii massovogo mediaobrazovanija v polikul'turnyj socium (metodologicheskie problemy) [Formation of ethno-cultural identity in integration of mass media education into poly-cultural society (methodological problems)]. Media Education. 2: 16-24. [in Russian]

Levitskaya, Fedorov, 2021 - Levitskaya A., Fedorov A. Theoretical model of media competence's development of teachers-to-be in the process of the analysis of manipulative media influences. Media Education. 17(2): 323-332. DOI: 10.13187/me.2021.1.323.

Masterman, 1996 - Masterman, L. (1996). Media education and human rights. Continuum. 9(2): 73-77. DOI: 10.1080/10304319609365706

Mikhaleva, 2020 - Mikhaleva, G.V. (2020). Opyt organizacii treningov dlja studentov po razvitiju mezhjetnicheskoj tolerantnosti sredstvami mediaobrazovanija [Experience of organizing workshops for students on promoting interethnic tolerance by means of media education]. Crede Experto. 3(26). [Electronic resource]. URL: http://ce.if-mstuca.ru/index.php/pedagogics/persmedia-hum-stud-in-media-edun/ootlsprmtsm-en [in Russian]

Ramasubramanian, 2007 - Ramasubramanian, S. (2007). Media-based strategies to reduce racial stereotypes activated by news stories. Journalism \& Mass Communication Quarterly. 84(2): 249-264. DOI: 10.1177/107769900708400204

Ramasubramanian, 2011 - Ramasubramanian, $S$. (2011). The impact of stereotypical versus counterstereotypical media exemplars on racial attitudes, causal attributions, and support for affirmative action. Communication Research. 38(4): 497-516. DOI: 10.1177/0093650210384854.

Rubtsova, 2013 - Rubtsova, O.V. (2013). Razvitie nacional'nyh tradicij i grazhdanskoj otvetstvennosti detej i molodezhi sredstvami mediateksta social'noj reklamy [Development of national traditions and civic responsibility of children and youth through the media of social advertising]. Media. Information. Communication. 7. [Electronic resource]. URL: http://mic.org.r u/vyp/7-nomer-2013/razvitie-natsionalnykh-traditsiy-i-grazhdanskoy-otvetstvennosti-detey-imolodezhi-sredstvami-mediate/ [in Russian]

Silverblatt, 2001 - Silverblatt, A. (2001). Media Literacy. Westport, Connecticut - London: Praeger. $449 \mathrm{p}$.

Strategy..., 2015 - Strategiya razvitiya vospitaniya v Rossiiskoi Federatsii na period do 2025 goda ot 29 maya 2015g. [Strategy for the development of education in the Russian Federation for the period up to 2025 dated May 29, 2015]. [Electronic resource]. URL: https://rg.ru/2015/o6/ o8/vospitanie-dok.html

Vinichenko, 2011 - Vinichenko, V.A. (2011). Formirovanie mezhjetnicheskoj tolerantnosti u budushhih specialistov po svjazjam s obshhestvennost'ju [Formation of interethnic tolerance among future public relations specialists]. PhD. Dis. Irkutsk. [in Russian]

Vinichenko, 2017 - Vinichenko, V.A. (2017). Metody mediaobrazovanija $\mathrm{v}$ formirovanii mezhkul'turnoj kompetencii bakalavrov reklamy i svjazej s obshhestvennost'ju [Methods of media education in the formation of intercultural competence of bachelors of advertising and public relations]. World of Science. 5(5). [Electronic resource]. URL: https://mir-nauki.com/PDF/66 PDMN517.pdf [in Russian] 
Vrabec, Bôtošová, 2020 - Vrabec, N., Bôtošová, L. (2020). The Concept of learning-by-doing in the context of media education and school quality assessment. Communication Today. 11(1): 140-148.

Weber, 2018 - Weber, B. (2018). In Permanent Crisis: Ethnicity in Contemporary European Media and Cinema. Ethnic and Racial Studies. 41(3): 609-611. DOI: 10.1080/01419870.2017. 1339902.

Worsnop, 2004 - Worsnop, C.M. (2004). Media Literary through critical thinking. Teacher Materials. [Electronic resource]. URL: https://mediaeducation.ucoz.ru/load/o-o-o-1092-20

Zhmyrova, Monastyrskiy, 2012 - Zhmyrova, E.Yu., Monastyrskiy, V.A. (2012). Kinoiskusstvo kak sredstvo vospitaniya tolerantnosti u uchashchejsya molodezhi [Cinematography as a means of fostering tolerance among students]. Tambov. [in Russian] 


\title{
Copyright (C) 2021 by Cherkas Global University
}

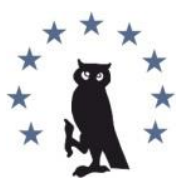

Published in the the USA

International Journal of Media and Information Literacy

Has been issued since 2016.

E-ISSN: $2500-106 \mathrm{X}$

2021. 6(2): $289-298$

DOI: 10.13187/ijmil.2021.2.289

https://ijmil.cherkasgu.press

\section{On My Own: Acquiring Technical Digital Skills for Mobile Phone Use in Chile. Parents-children Perceptions}

\author{
Beatriz Feijoo ${ }^{\mathrm{a}, ~}{ }^{*}$, Charo Sádaba $^{\mathrm{b}}$, Gemma Martínez $^{\mathrm{c}}$ \\ ${ }^{a}$ Universidad Internacional de la Rioja, Spain \\ b University of Navarra, Spain \\ c University of Basque Country, Spain
}

\begin{abstract}
Despite its relevance, the difficulty in reaching consensus on the definition of digital competence slows down its implementation. The need of prior development of specific skills to advance in digital development has been recently reported. The acquisition of skills involves making the most of the opportunities offered by the digital environment. This article shows the results from a research conducted on 501 parent-child dyads in Chile in which minors aged 10 to 14 reported their self-perceptions on who (parents, siblings and peers) taught them certain technical and operational digital skills on mobile devices. Parents were also surveyed to know their perception about this children's social mediation. Socio-demographic variables are also analysed. Chilean minors have a clear perception of autonomy in the acquisition of digital competence, parents underestimate their ability to influence, and other socialization agents such as siblings play a significant role. Age, gender and socioeconomic level to a lesser extent mark differences in the acquisition of these skills. In addition to providing a comparison on the perception parents and children have on the extent to which minors are accompanied while on their mobile phone, the article goes beyond parental mediation strategies and collects parental reflections on types of mediation.
\end{abstract}

Keywords: digital competence, technical skills, safety skills, mobile phone, children.

\section{Introduction}

Access to and use of internet and the appropriation of different digital devices among Chilean families, as is happening in other Western societies has increased significantly in recent years. Not surprisingly, $87.4 \%$ of Chilean households have paid access to the internet and reaches $94 \%$ in those households in which there are children going to school, a trade school or university (Subtel, 2017). On the other hand, the study developed in 2016 by Kids Online Chile, coinciding with the tendency of our results, shows that $92 \%$ of children aged 9 to 17 could access the Internet at home via a mobile phone (Cabello et al., 2017). This new digitalised household has had an impact on children's uses and practises and on their digital skills development both, as individual internet users as well as individuals influenced by different social mediators such as the family or peers.

Digital competences and digital skills acquisition by children has been identified as an essential precondition for minors' development and their general well-being (Livingstone et al., 2018; Smahel et al., 2020). A research developed in Chile (Cabello et al., 2018) shows that sociodemographic factors such as age and socioeconomic status are significantly associated with different level of skills with

\footnotetext{
* Corresponding author

E-mail addresses: beatriz.feijoo@unir.net (B. Feijoo)
} 
children showing higher levels of digital competence as their age increases and among those with the highest socioeconomic status. Evidence also shows that children owning a mobile phone with internet access developed higher digital skills (Cabello et al., 2018).

Parents, as social mediators of their children's online activities try to find a difficult balance between their children's online safety while aiming to maximise their digital opportunities and digital skills. We consider essential to analyse under children and parents perspectives how children acquire specific safety and other digital skills regarding the smartphones use, with special focus on their level of autonomy performing these skills as well as the implication of different individuals (parents, siblings and peers) with teaching them these skills.

In sum, this article aims to understand how children have adopted smartphones in the household and how involved parents get in this process, the most frequent activities developed on their smartphones and the perceptions that parents and children have about the same minor's technical and operational digital skills on these devices.

\section{Materials and methods}

The aim of this study is to determine children's digital skills regarding online safety and privacy in using smartphones, namely children's and parents' self-reported ability to manage various aspects related to smartphone configuration and online safety, as well as other operational skills implicit in their use. Other elements implicit in the process of acquisition and development of these skills have also been taken into account, such as internet connection features, smartphone ownership, range of minors' online activities, as well as the influence of sociodemographic factors (age, gender and socioeconomic status.)

To answer this objective, the following research questions were proposed:

1) What abilities do children self-report and what abilities do parents perceive their children as having regarding the operational digital skills required to configure mobile phones, install applications, and protect themselves from advertising messages?

2) What abilities do children self-report and what abilities do parents perceive their children as having regarding their children's operational digital skills with regard to online safety and privacy on smartphones?

3) Are there significant differences in the responses among minors based on individual sociodemographic factors (age, gender and socioeconomic status)?

Quantitative methodology with data collected in face-to-face surveys was used. The universe selected for this study were households with minors ages 10 to 14 in the Metropolitan Area of Santiago de Chile. A 501 households sample size was defined for the survey, each home of which was to include and survey a residing child who met the sought profile and one of their parents or legal guardian (501 minors and 501 adults.)

According to the 2017 Chilean Census, the latest available, the Metropolitan Area has 373,129 homes with children ages 10 to 14 distributed as follows in the geographic sectors or macrozones commonly and locally used: Center $=47,148$ homes; North $=50,553$; East $=69,954$; West $=73,877$; South $=131,597$.

Each macrozone was assigned 100 cases and the sample was distributed proportionally according to the percentage of households with children ages 10 to 14 per borough (locally known as "comuna") that make up each macrozone. This distribution resulted in a probabilistic design by areas (macrozones) with an error of $\pm 4.4 \%$ under the assumptions of simple random sampling and $95 \%$ confidence. The field work was performed between May and July 2018.

A close-ended question with a multiple responses answer was designed for this study. The question was "Who taught you to do the following activities?", and SPSS analyzable multiple responses were: Never done it (1), Don't know how to (2), Learned by myself (3), A parent (4), A sibling (5), A friend (6), Another person [another relative: uncle/aunt, grandparents, cousins; at school/teacher] (88), DK / NA (99).

During the visit to each household, and prior to surveying the adult and the minor separately, parents signed a parental consent form previously approved by the Ethics Committee of the University seconding this research project. With regards to format, both groups answered the same survey; in relation to the question, both groups were asked the same questions, but from different approaches. Given the object of research in this study is minors, the questionnaire was aimed at them, and thus, they were asked about their own habits and experiences with mobile devices. 
Contrastingly, parents/guardians were requested to answer according to their perception of the same reality. Specifically, children and adults were asked about the items listed in Table 1.

Table 1. Descriptive statistics of the elements of the analysis

\begin{tabular}{|l|c|c|c|c|c|c|c|c|}
\hline Item & \multicolumn{4}{|c|}{ Minors $(\boldsymbol{\alpha}=\mathbf{. 8 0 3})$} & \multicolumn{4}{c|}{ Adults $(\boldsymbol{\alpha}=. \mathbf{9 1 5})$} \\
\hline & $\mathbf{N}$ & $\mathbf{M}$ & $\mathbf{S}^{\mathbf{2}}$ & $\mathbf{D T}$ & $\mathbf{N}$ & $\mathbf{M}$. & $\mathbf{S}^{\mathbf{2}}$ & DT \\
\hline Phone settings configuration & 485 & 3.44 & 1.37 & 1.17 & 467 & 3.48 & 1.43 & 2.04 \\
\hline Privacy settings configuration & 491 & 2.81 & 1.94 & 1.39 & 442 & 2.76 & 1.62 & 1.27 \\
\hline Adblockers activation & 490 & 2.33 & 1.72 & 1.31 & 427 & 2.55 & 1.54 & 1.24 \\
\hline Email account creation & 472 & 3.09 & 2.15 & 1.47 & 457 & 2.88 & 1.62 & 1.27 \\
\hline Social media sign-up & 484 & 3.22 & 1.92 & 1.39 & 465 & 3.11 & 1.29 & 1.14 \\
\hline App store management & 491 & 2.63 & 1.79 & 1.34 & 457 & 3.04 & 1.13 & 1.06 \\
\hline Apps installation & 485 & 3.19 & .93 & .96 & 474 & 3.23 & .92 & .96 \\
\hline
\end{tabular}

The Bonferroni test was used to determine the existence of significant differences when working with different bases, between the responses of the two samples established and on which the surveys were applied. The statistical data presented in this analysis belong to the first phase of a broader investigation collected in the Fondecyt Initiation $\mathrm{N}^{\circ} 11170336$, financed by the National Commission for Scientific and Technological Research (CONICYT) of the Government of Chile.

This article aims to contribute to a better understanding of role children have in the mechanisms of media, considering at all times their developmental state and moment in their education and striving to respect and defend their dignity and rights as a human beings. To safeguard the integrity of participants and researchers prior to collecting the data here analyzed. Written authorization was requested from the guardian who signed an informed consent and the minors themselves were also asked for their assent. These documents were reviewed and validated by the Ethics Committee of the university to which this research project is linked (Universidad de los Andes, Chile).

\section{Discussion}

Concerns have been raised due to the intensiveness of the use of screens, mainly with regard to the sheer amount of time devoted to them (Chassiakos et al., 2016) while the potential negative effect of screen time over youngster' wellbeing has been recently questioned (Orben, Przybylski, 2019). It is what young people do while enjoying themselves with these screens rather than the amount of time spent on them that seems to be worthy of analysis (Blum-Ross, Livingstone, 2018, 2016).

Besides this, the current lack of common definitions and understanding among the scientific community of concepts such as digital skills, digital competence and digital literacy increases the difficulty for the design of global and systematic strategies that can help in the development of these concepts among minors (Donoso et al., 2021; Haddon et al., 2020). Evidence shows that the level of digital skills of minors is positively associated with the frequency and variety of activities (Livingstone et al., 2019) in which minors get involved online (Cabello et al., 2018).

The acquisition of digital skills which lead to digital competence is an essential precondition for minors' development and general well-being (Livingstone et al., 2018; Smahel et al., 2020). Among the antecedents that can facilitate or hinder its acquisition, individual characteristics of minors such as sociodemographic factors (age and gender), social characteristics (socioeconomic status and parental mediation), characteristics of the country where they live and others related to their own use of the internet, access, as well as their perception of effectiveness in the use of the internet, and preference for online social interactions (Cabello et al., 2020; Haddon et al., 2020; Garmendia et al., 2019; Livingstone, Helsper, 2010; Mascheroni et al., 2020; Trucco, Palma, 2020).

This research devotes special attention to those skills associated with the process of acquisition and the ability of the child when using technical and safety possibilities of the smartphones, that are part of the technical and operational skills proposed in the context of the EU Kids Online project (Van Deursen et al., 2016) and later reviewed and updated (Helsper et al., 2021). Besides the technical and operational skills these authors also identified navigation and information process skills; communication and interaction skills and content creation and production skills. 
Online safety skills become particularly relevant in the case of access through smartphones (Mascheroni, Ólafsson, 2014), as the use of these devices increase the degree of individualization and make it difficult to reconcile parental involvement with respect for the limits of privacy and autonomy of their children (Haddon et al., 2018). This situation becomes a challenge for parents (Berrios et al., 2015; Condeza et al., 2019) who are expected to act as "facilitating" mediators (Livingstone et al., 2017; Martínez et al., 2020; Rodríguez-de-Dios et al., 2018;) of the digital activities their children get involved in, to strengthen the development of skills for digital competence (Ferrari, 2013; Van Deursen et al., 2016) and at the same time, to be the guardians their own children's online safety and digital well-being (Smahel et al., 2020).

While the role of parents as mediators of their children's online activities has been widely studied by parental mediation specialists, with a focus on issues such as child protection and online safety (Berrios et al., 2015; Jiménez-Morales et al., 2020; Martínez et al., 2020) very few studies have considered the perception of parents about their role in the process of acquisition of digital competences or skills by the child compared with children's own perception.

\section{Results}

As stated in the methodology, 501 homes in the Metropolitan Area of Santiago de Chile were found to meet research criteria and accepted to participate. At each household, a minor (ages 10 to 14) and one of their parents or guardians was surveyed, which resulted in 1002 respondents.

Samples of minors can be described as follows, 300 (6o \%) were ages 10 and 12, and 201 ( $40 \%$ ) were ages 13 to $14 ; 230$ (46\%) were boys and 271 (54\%) girls. Most frequently, children live in households with four or more members $(\mathrm{N}=388 ; 77.2 \%)$ and socioeconomic levels were distributed as follows: upper stratum (C1): $7.2 \%(\mathrm{~N}=36)$; middle stratum $\left(\mathrm{C}_{2}\right.$ and $\left.\mathrm{C}_{3}\right): 46.9 \%$ $(\mathrm{N}=235)$; low stratum (D): $42.9 \%(\mathrm{~N}=215)$; NS / NC: $3 \%(\mathrm{~N}=15)$. Regarding adults, most were women $(\mathrm{N}=411 ; 82 \%)$, and the child's mother (93\%).

By far smartphones (99.2 \%) is the device with the highest penetration rate in Chilean homes. About $50 \%$ of the sampled homes have a laptop and tablet, and desktop computers (40 \%) are less common among the individuals surveyed.

Specific operational online safety skills are analyzed here, such as the ability to configure the device itself, privacy settings, or ad-blockers, and others such as the ability to create email accounts or sign up on social networks, download applications or manage applications stores. Three dimensions were studied in relation to the general configuration of mobile phones, and most frequently minors stated they had learned by themselves. As shown on Table 2, more than $50 \%$ asserted having configured their mobile phone settings on their own, $35.7 \%$ for privacy settings and $36.1 \%$ for the activation of ad-blockers. Regarding privacy settings, it is noteworthy that one in three minors acknowledged that they have never configured the privacy settings of their phone or that they did not know how to do so, a pattern that becomes even more evident when asked about the activation of ad-blockers: practically $40 \%$ said they had not tried to use any of such services and $11.6 \%$ said they were unable to operate them. Beyond their self-sufficiency, for all three phone configuration actions, children indicated parents were their main reference. The accompaniment provided by siblings, in terms of percentage is higher than that of friends, for both parents and minors surveyed.

In their responses, parents recognized that their children essentially learn to handle mobile phones by themselves. For all three dimensions analyzed, adults mostly chose "I learned by myself", as their children's answer especially when referring to phone settings configuration (50.7\%). It is interesting to note that the role of parents tends to be more valued by minors than by the adults themselves.

Along these lines, adults considered that their largest contribution is in configuring privacy settings, which coincides with what minors also highlight. However, adults tended to overestimate their minor's ability to manage ad-blockers: statistically significant differences were found between the number of times adults and minors chose "I have never done it" and "I don't know how to do it" as answers to this dimension.

When responses from minors are segmented by gender, age and socioeconomic level, certain significant differences are found, especially those associated to age. As Table 3 shows, children ages 13 to 14 tend to perform activities on their own to a greater extent than those ages 10 to 12 , who seem to rely more on their parents. Regarding gender, ad-blockers configuration is more widespread among boys than girls. With regard to socioeconomic level, although statistically 
significant differences were practically absent, parental mediation seems to be more present among higher strata, while sibling mediation tends to outweigh the former in lower levels.

Table 2. Perception by adults and responses by minors on the accompaniment provided to minors while acquiring digital skills related to online safety in the use of mobile phones

\begin{tabular}{|c|c|c|c|}
\hline & & $\begin{array}{l}\text { ADULT (\%) } \\
(\mathrm{N}=501)\end{array}$ & $\begin{array}{l}\text { MINOR(\%) } \\
(\mathrm{N}=501)\end{array}$ \\
\hline \multirow[t]{8}{*}{ Phone settings configuration } & Never done it & 11.2 & 8.2 \\
\hline & Do not know how & 1.6 & 1.2 \\
\hline & Learned by myself & 50.7 & 50.5 \\
\hline & A parent* & 0.2 & 18.8 \\
\hline & A sibling* & 20.2 & 13.0 \\
\hline & A friend * & 9.4 & 5.2 \\
\hline & Another person* & 1.2 & 3.2 \\
\hline & DK/NA & 5.6 & 0.0 \\
\hline \multirow[t]{8}{*}{ Privacy settings configuration } & Never done it & 24.0 & 27.7 \\
\hline & Do not know how to & 4.6 & 5.4 \\
\hline & Learned by myself & $35 \cdot 7$ & 36.7 \\
\hline & A parent & 16.8 & 16.2 \\
\hline & A sibling & 6.8 & 9.4 \\
\hline & A friend & 0.4 & 2.6 \\
\hline & Another person & 1.2 & 2.0 \\
\hline & DK/NA & 10.6 & 0.0 \\
\hline \multirow[t]{8}{*}{ Adblockers activation } & Never done it* & 27.1 & 39.1 \\
\hline & Do not know how to* & 6.2 & 11.4 \\
\hline & Learned by myself & 36.1 & 31.9 \\
\hline & A parent & 9.8 & 8.4 \\
\hline & A sibling & 6.0 & 5.4 \\
\hline & A friend & 0.0 & 1.6 \\
\hline & Another person & 0.8 & 2.2 \\
\hline & $\mathrm{DK} / \mathrm{NA}$ & 14.0 & 0.0 \\
\hline
\end{tabular}

* Statistically significant result between Adult and Minor sample. Results are based on twosided tests with a significance level of .05. Tests are adjusted for all pairwise comparisons within a row of each subtable using the Bonferroni correction.

As in the previous section, the analysis of more specific actions on smartphones, such as creating email accounts or profiles on social networks, installing apps or browsing application stores, reveals the extent to which self-learning is relevant among minors. For all the dimensions studied in this section, the most frequent response was "I learned alone", especially when referring to accessing catalogs and downloading and signing up on social network apps, for which more than $40 \%$ of the sample declared to have done these activities independently. However, for the creation of email accounts, minors stated relying more on parents (20.8\%) and siblings (14.4\%).

Indeed, for these activities, parents are the second source from which to learn, especially for creating email accounts, as 1 in 5 minors turned to them for help. Likewise, in the rest of the actions analyzed in this section, parental figures rank second. Friends play a more significant role in this type of skill acquisition, for example in the creation of profiles on social networks (6.8\%), an influence parents do not seem to be aware of. As noted in the previous section, the relevance of the role of siblings follows that of parents, especially in the creation of email accounts.

Table 3. Segmentation by gender, age and SES of the minor's responses about the accompaniment minors receive while acquiring digital skills related to security in the use of mobile phones

\begin{tabular}{|c|c|c|c|c|c|c|c|c|c|}
\hline & \multicolumn{2}{|c|}{ GENDER (\%) } & \multicolumn{2}{|c|}{ AGE (\%) } & \multicolumn{4}{|c|}{ SES (\%) } \\
\hline & & Boys & Girls & 10 to 12 & 13 to & $\mathrm{C} 1$ & $\mathrm{C} 2$ & $\mathrm{C}_{3}$ & $\mathrm{D}$ \\
\hline \multirow{2}{*}{$\begin{array}{l}\text { Phone } \\
\text { settings }\end{array}$} & Never done it & 7.8 & 8.5 & 10.0 & 5.4 & 0.0 & 7.6 & $7 \cdot 7$ & 10.7 \\
\hline & Do not know how to & 0.4 & 1.9 & 1.7 & 0.5 & 2.8 & 1.1 & 0.7 & 1.4 \\
\hline
\end{tabular}




\begin{tabular}{|c|c|c|c|c|c|c|c|c|c|}
\hline \multirow{6}{*}{$\begin{array}{l}\text { configur } \\
\text { ation }\end{array}$} & Learned by myself & 52.4 & 48.9 & 43.8 & $60.4^{*}$ & 55.6 & $53 \cdot 3$ & 53.1 & 46.0 \\
\hline & A parent & 19.0 & 18.5 & $22.4^{*}$ & 13.4 & $33 \cdot 3$ & 19.6 & 17.5 & 16.7 \\
\hline & A sibling & 13.0 & 13.0 & 13.4 & 12.4 & 2.8 & 13.0 & $13 \cdot 3$ & 14.9 \\
\hline & A friend & 4.8 & 5.6 & 5.4 & 5.0 & 0.0 & $4 \cdot 3$ & 5.6 & 6.0 \\
\hline & Another person & 2.6 & 3.7 & $3 \cdot 3$ & 3.0 & 5.6 & 1.1 & 2.1 & 4.2 \\
\hline & $\mathrm{DK} / \mathrm{NA}$ & 0.0 & 0.0 & 0.0 & 0.0 & 0.0 & 0.0 & 0.0 & 0.0 \\
\hline \multirow{8}{*}{$\begin{array}{l}\text { Privacy } \\
\text { settings } \\
\text { configur } \\
\text { ation }\end{array}$} & Never done it & 28.6 & 27.0 & $33.8^{*}$ & 18.8 & 19.4 & $39.1^{*}\left(C_{3}\right)$ & 20.3 & 30.7 \\
\hline & Do not know how to & 6.9 & 4.1 & 6.7 & 3.5 & 8.3 & 2.2 & 5.6 & 6.5 \\
\hline & Learned by myself & 32.9 & 40.0 & 26.4 & $52.0^{*}$ & 38.9 & 22.8 & $43.4^{*}(\mathrm{C} 2)$ & 36.3 \\
\hline & A parent & 15.6 & 16.7 & $20.1^{*}$ & 10.4 & 27.8 & 19.6 & 18.2 & 12.1 \\
\hline & A sibling & 10.4 & 8.5 & 8.7 & 10.4 & 2.8 & 13.0 & 7.7 & 10.2 \\
\hline & A friend & 3.5 & 1.9 & 1.7 & 4.0 & 2.8 & 2.2 & 3.5 & 1.4 \\
\hline & Another person & 2.2 & 1.9 & 2.7 & 1.0 & 0.0 & 1.1 & 1.4 & 2.8 \\
\hline & DK/NA & 0.0 & 0.0 & 0.0 & 0.0 & 0.0 & 0.0 & 0.0 & 0.0 \\
\hline \multirow{8}{*}{$\begin{array}{l}\text { Adblock } \\
\text { ers } \\
\text { activa } \\
\text { tion }\end{array}$} & Never done it & 36.4 & 41.5 & $44.1^{*}$ & 31.7 & 27.8 & 46.7 & 37.8 & 40.0 \\
\hline & Do not know how to & 9.5 & 13.0 & 11.7 & 10.9 & 19.4 & 8.7 & $13 \cdot 3$ & 10.2 \\
\hline & Learned by myself & $36.8^{*}$ & 27.8 & 25.8 & $41.1^{*}$ & 30.6 & 25.0 & 35.0 & 31.6 \\
\hline & A parent & 9.1 & 7.8 & 10.4 & $5 \cdot 4$ & 13.9 & 9.8 & 8.4 & 7.4 \\
\hline & A sibling & 4.3 & 6.3 & 4.7 & 6.4 & 2.8 & 7.6 & 2.8 & 6.5 \\
\hline & A friend & 1.3 & 1.9 & 1.3 & $2.0 \%$ & 0.0 & 2.2 & 1.4 & 1.9 \\
\hline & Another person & 2.6 & 1.9 & 2.0 & $2.5 \%$ & 5.6 & 0.0 & 1.4 & 2.3 \\
\hline & $\mathrm{DK} / \mathrm{NA}$ & 0.0 & 0.0 & 0.0 & $0.0 \%$ & 0.0 & 0.0 & 0.0 & 0.0 \\
\hline
\end{tabular}

* Statistically significant result between columns within the same variable (Sex, Age, SES). Results are based on twosided tests with a significance level of, 05. Tests are adjusted for all pairwise comparisons within a row of each subtable using the Bonferroni correction.

Table 4. Perception by adults and responses by minors on the accompaniment provided to minors while learning other digital skills on their mobile phones (email account, profile in social media or management of app stores)

\begin{tabular}{|c|c|c|c|}
\hline & & $\begin{array}{c}\text { ADULT (\%) } \\
(\mathrm{N}=501)\end{array}$ & $\begin{array}{l}\text { MINOR(\%) } \\
(\mathrm{N}=501)\end{array}$ \\
\hline \multirow[t]{8}{*}{ Email account creation } & Never done it & 22.8 & 23.0 \\
\hline & Do not know how to & 2.4 & 4.6 \\
\hline & Learned by myself * & 37.7 & 28.3 \\
\hline & A parent & 20.0 & 20.8 \\
\hline & A sibling * & 8.0 & 14.4 \\
\hline & A friend * & .4 & 3.2 \\
\hline & Another person * & 1.6 & 5.8 \\
\hline & $\mathrm{DK} / \mathrm{NA}$ & 7.2 & 0.0 \\
\hline \multirow[t]{8}{*}{ Social media sign-up } & Never done it & 13.6 & 17.0 \\
\hline & Do not know how to & 1.0 & 2.2 \\
\hline & Learned by myself * & 51.9 & 44.1 \\
\hline & A parent & 16.0 & 15.8 \\
\hline & A sibling & 8.8 & 10.8 \\
\hline & A friend * & 1.6 & 6.8 \\
\hline & Another person * & 1.4 & 3.4 \\
\hline & $\mathrm{DK} / \mathrm{NA}$ & 5.8 & 0.0 \\
\hline \multirow[t]{8}{*}{ App store management } & Never done it $*$ & 12.6 & 31.3 \\
\hline & Do not know how to* & 1.4 & 5.2 \\
\hline & Learned by myself * & 56.5 & 41.1 \\
\hline & A parent & 12.0 & 12.0 \\
\hline & A sibling * & 8.0 & 5.8 \\
\hline & A friend & .8 & 2.6 \\
\hline & Another person & 1.4 & 2.0 \\
\hline & $\mathrm{DK} / \mathrm{NA}$ & 7.4 & 0.0 \\
\hline \multirow[t]{5}{*}{ Apps installing } & Never done it & 7.6 & $7 \cdot 4$ \\
\hline & Do not know how to & 1.0 & 1.0 \\
\hline & Learned by myself * & 58.7 & 66.3 \\
\hline & A parent* & 18.0 & 12.2 \\
\hline & A sibling & 8.4 & 7.8 \\
\hline
\end{tabular}




\begin{tabular}{|l|l|l|}
\hline A friend & 1.0 & 2.2 \\
\hline Another person * & 1.0 & 3.2 \\
\hline DK/NA & 4.4 & 0.0 \\
\hline
\end{tabular}

As happened when collecting data on other dimensions, parents stated that their minors learn these skills on their own. In most of the cases analyzed, the percentage of parents who responded that minors learned on their own is greater than that declared by the minors themselves. Significant differences are indicated in Table 4, and point at parental overestimation of their children's ability to learn on their own. Similarly, adults also tended to overestimate how easily and knowledgeably minors interact with app stores.

As happens when parents are asked about how minors learn to configure their smartphones, and equally noteworthy is the fact that many chose not to answer the questions presented for the analysis of this dimension, either due to ignorance or for other unknown reasons (between $4.4 \%$ and $7.4 \%)$.

Table 5. Segmentation by gender, age and SES of the child's responses about the accompaniment minors receive while learning the digital skills stated

\begin{tabular}{|c|c|c|c|c|c|c|c|c|c|}
\hline & \multicolumn{2}{|c|}{ GENDER (\%) } & \multicolumn{2}{|c|}{ AGE (\%) } & \multicolumn{4}{|c|}{ SES (\%) } \\
\hline & & Boys & Girls & 10 to 12 & 13 to 14 & $\mathrm{C} 1$ & $\mathrm{C} 2$ & C3 & $\mathrm{D}$ \\
\hline \multirow{8}{*}{$\begin{array}{l}\text { Email } \\
\text { account } \\
\text { creation }\end{array}$} & Never done it & 23.4 & 22.6 & $28.1^{*}$ & $15 \cdot 3$ & 19.4 & $35 \cdot 9^{*}(\mathrm{D})$ & 21.7 & 19.1 \\
\hline & Do not know how to & 3.9 & 5.2 & $5 \cdot 7$ & 3.0 & 5.6 & $3 \cdot 3$ & 4.9 & 5.1 \\
\hline & Learned by myself & $35 \cdot 9^{*}$ & 21.9 & 21.7 & $38.1^{*}$ & 30.6 & 22.8 & 32.2 & 27.0 \\
\hline & A parent & 16.5 & $24.4^{*}$ & 22.7 & 17.8 & $36.1^{*}(\mathrm{D})$ & 21.7 & 22.4 & 16.7 \\
\hline & A sibling & 13.9 & 14.8 & 13.4 & 15.8 & 0.0 & 14.1 & 11.2 & 19.1 \\
\hline & A friend & 2.2 & 4.1 & 2.7 & 4.0 & 2.8 & 0.0 & 0.7 & $6.5^{*}\left(\mathrm{C}_{3}\right)$ \\
\hline & Another person & $4 \cdot 3$ & 7.0 & $5 \cdot 7$ & 5.9 & 5.6 & 2.2 & 7.0 & 6.5 \\
\hline & $\mathrm{DK} / \mathrm{NA}$ & 0.0 & 0.0 & 0.0 & 0.0 & 0.0 & 0.0 & 0.0 & 0.0 \\
\hline \multirow{8}{*}{$\begin{array}{l}\text { Social } \\
\text { media } \\
\text { sign-up }\end{array}$} & Never done it & 16.0 & 17.8 & $22.4^{*}$ & 8.9 & 16.7 & 12.0 & 16.8 & 19.1 \\
\hline & Do not know how to & 2.6 & 1.9 & 3.0 & 1.0 & 2.8 & 0.0 & .7 & 4.2 \\
\hline & Learned by myself & 46.8 & 41.9 & 36.1 & $55 \cdot 9^{*}$ & 50.0 & $56.5^{*}(\mathrm{D})$ & 41.3 & 39.5 \\
\hline & A parent & 16.9 & 14.8 & $19.7^{*}$ & 9.9 & 19.4 & 16.3 & 18.9 & 13.0 \\
\hline & A sibling & 10.4 & 11.1 & 9.7 & 12.4 & 5.6 & 6.5 & $13 \cdot 3$ & 12.1 \\
\hline & A friend & 3.9 & $9.3^{*}$ & 6.0 & 7.9 & 5.6 & 7.6 & 4.2 & 8.4 \\
\hline & Another person & 3.5 & $3 \cdot 3$ & 3.0 & 4.0 & 0.0 & 1.1 & 4.9 & 3.7 \\
\hline & $\mathrm{DK} / \mathrm{NA}$ & 0.0 & 0.0 & 0.0 & 0.0 & 0.0 & 0.0 & 0.0 & 0.0 \\
\hline \multirow{8}{*}{$\begin{array}{l}\text { Applicati } \\
\text { on store } \\
\text { manage } \\
\text { ment }\end{array}$} & Never done it & 21.6 & $39.6^{*}$ & 34.4 & 26.7 & 25.0 & 26.1 & 29.4 & 36.7 \\
\hline & Do not know how to & $3 \cdot 5$ & 6.7 & 5.0 & $5 \cdot 4$ & 5.6 & 7.6 & 4.9 & 3.7 \\
\hline & Learned by myself & $46.3^{*}$ & 36.7 & 38.8 & 44.6 & 47.2 & $45 \cdot 7$ & 45.5 & 34.9 \\
\hline & A parent & $15.6^{*}$ & 8.9 & 12.7 & 10.9 & 13.9 & 14.1 & 14.0 & 10.2 \\
\hline & A sibling & 7.4 & 4.4 & $5 \cdot 4$ & 6.4 & 0.0 & $3 \cdot 3$ & 4.2 & 8.8 \\
\hline & A friend & 2.6 & 2.6 & 2.0 & $3 \cdot 5$ & 5.6 & $3 \cdot 3$ & 0.0 & 3.7 \\
\hline & Another person & 3.0 & 1.1 & 1.7 & 2.5 & 2.8 & 0.0 & 2.1 & 1.9 \\
\hline & $\mathrm{DK} / \mathrm{NA}$ & 0.0 & 0.0 & 0.0 & 0.0 & 0.0 & 0.0 & 0.0 & 0.0 \\
\hline \multirow{8}{*}{$\begin{array}{l}\text { Apps } \\
\text { installati } \\
\text { on }\end{array}$} & Never done it & 6.9 & 7.8 & $9.4^{*}$ & 4.5 & 2.8 & $3 \cdot 3$ & 5.6 & 11.2 \\
\hline & Do not know how to & 1.3 & .7 & 1.0 & 1.0 & 0.0 & 0.0 & 0.0 & 2.3 \\
\hline & Learned by myself & 67.1 & 65.6 & 61.2 & $73.8^{*}$ & 66.7 & 65.2 & 72.0 & $63 \cdot 3$ \\
\hline & A parent & 11.7 & 12.6 & $14.7^{*}$ & 8.4 & $25 \cdot 0^{*}(\mathrm{D})$ & 16.3 & 14.7 & 7.0 \\
\hline & A sibling & 5.6 & 9.6 & 8.0 & 7.4 & 2.8 & 10.9 & 4.9 & 9.3 \\
\hline & A friend & 3.5 & 1.1 & 2.0 & 2.5 & 0.0 & 2.2 & 1.4 & 2.8 \\
\hline & Another person & 3.9 & 2.6 & 3.7 & 2.5 & 2.8 & 2.2 & 1.4 & 4.2 \\
\hline & $\mathrm{DK} / \mathrm{NA}$ & 0.0 & 0.0 & 0.0 & 0.0 & 0.0 & 0.0 & 0.0 & 0.0 \\
\hline
\end{tabular}

Segmentation by gender, age and SES reveals that age is the variable that once again marks significant differences: the older children are, the more they tend to learn on their own. As Table 5 shows, the percentage of minors ages 10 to 12 who have never created an email account, signed up on social networks or installed apps is significant. This situation changes, however in the sample ages 13 and 14 in which the percentage increases. In any case, it should be noted that $36.1 \%$ of minors ages 10 to 12 revealed having signed up for social networks by themselves, an age at which 
registration is theoretically not allowed. Signing up for social media is also the routine for which minors aged 10 to 12 declared they had had most support from their parents (19.7 \%) followed by apps installations (14.7\%). Minors ages 13 and 14 confirmed having received help from their parents (17.8 \%) and siblings (15.8 \%) in creating an email account. However, when creating profiles on social networks, they turn to siblings (12.4\%) more than to parents (9.9\%).

Although the gender variable does not seem to be decisive, boys tend to be more independent than girls in acquiring digital skills. Regarding the socioeconomic level, although no statistically significant differences were found, it is once again observed that the percentage of minors who declared having learned with their parents tends to be lower in the most disadvantaged strata. I these cases, minors tend to rely more on siblings.

\section{Conclusion}

This paper seeks to provide evidence on the role played by next of kin, peers and others (parents, siblings, peers) in the process of acquiring an ability among Chilean children. Minors' perception was completed with the parents' view on the mediation they believe their children had received throughout the process.

According to the data, Chilean homes could be an ideal place for the development of children's digital skills given the wide variety of mobile digital devices that can be made available. Both the variety of technologies available for minors at home and the chance to access the network autonomously is related to the acquisition of digital skills (Haddon et al., 2020). Particularly noteworthy is the high penetration of smartphones, which has increased 7 percentage points compared to that reported in previous studies (Cabello et al., 2017) and now practically reaches $100 \%$, and is the most widely owned device among minors.

As far as operational digital skills related to smartphone online safety and privacy are concerned, most of the minors surveyed stated that they autonomously configure general and privacy aspects of their mobile phone, and activate ad-blockers. Parental involvement ranks second when it comes to more specific operational skills of the use of the smartphone, such as creating an email account, signing up on social networks or dealing with the acquisition of apps.

Interestingly, the autonomy minors perceive for themselves is shared by their parents, who seem to be aware that minors tend to learn on their own. In addition, minors mentioned parents as having been responsible for their digital learning more than the adults refer to themselves, which is consistent with previous research that showed that parents underestimate to a certain extent their self-efficacy in managing their use of internet compared to that of their children (Garmendia et al., 2019; Mascheroni et al., 2016).

The role of older siblings as digital mediators seems of interest. The data collected shows that for specific skills a higher percentage of children chose their siblings over friends for advice. This is particularly relevant in the specific field of digital competence development given that there is evidence that points to the importance of the mediating role of peers, family and schools in situations minors consider annoying or upsetting (Smahel et al., 2020; Garmendia et al., 2019).

1 in 3 minors stated not paying attention to the privacy settings of their mobile phone. These would show that, although the mobile phone access scene seems to be dominated by a perception of minors' autonomy, attention to key steps for safe and responsible browsing is not present.

The highest level of minor self-sufficiency was detected in app store management and social networks sign-up, for which almost $60 \%$ of the sample confirmed that they had learned by themselves. It is also necessary to highlight the level of autonomy minors declare when signing up for social networks, an action to which theoretically the vast majority of respondents should not have had access since the legally required age to open an account is 13 to 14 (age varies among platforms and requires parental consent.)

Finally, as in previous studies (Mascheroni et al., 2020; Haddon et al., 2020; Trucco, Palma, 2020), age was a determining variable. In general, minors ages 13 and 14 reported having learned on their own to a greater extent than 10- to 12-year-olds, who stated they turned to their parents to perform the proposed actions. Parents are taken into account more by children ages 10 to 12; however, it is interesting to observe that siblings acquire more relevance among those 13 and 14 .

Segmentation by gender reveals that more boys than girls tend to claim themselves to be independent in learning digital skills. By socioeconomic level of the household, the parental role in the acquisition of the analyzed skills in lower economic strata is less prevalent. There is a need to know to whom minors resort for their training in digital competence. 
The added value of this study lies in introducing into the debate about children's' digital skills acquisition the parents perception about it and their role. However, the exploratory approach of the study and methodological limitations do not allow the authors to discern the level of trust parents place on their children's self-learning capacity, if they consider that it is applies both technically and critically and if it is sufficient. Having answers to these new research questions by applying qualitative methods and delving into the role that parents play in the development of their children's digital competence with the mobile phone would be of great advantage.

\section{References}

Berrios et al., 2020 - Berrios, L., Buxarrais, M.R., Garcés, M.S. (2015). ICT use and parental mediation perceived by Chilean children. Comunicar. 22(45): 161-168.

Blum-Ross, Livingstone, 2016 - Blum-Ross, A., Livingstone, S. (2016). Families and screen time: current advice and emerging research. In Gangadharan, S.P. (ed.), Media Policy Project Policy Brief Series. Vol. 17. London School of Economics.

Blum-Ross, Livingstone, 2018 - Blum-Ross, A., Livingstone, S. (2018). The Trouble with "Screen Time" Rules. In Mascheroni, G. et al. (eds.). Digital Parenting. The Challenges for Families in the Digital Age. Sweden: Nordicom: 179-187.

Cabello et al., 2017 - Cabello, P., Claro, M, Lazcano. D. Antezana, L., Maldonado, L. (2017). Implementación de estudio de usos, oportunidades y riesgos en el uso de TIC por parte de niños, niñas y adolescentes en Chile: Informe final. Pontificia Universidad Católica de Chile. MINEDUC y UNESCO-OREALC. [Electronic resource]. URL: http://www.biblioteca.digital.gob.cl/bitstream/ handle/123456789/1409/Informe\%20final\%20Kids\%20Online.pdf?sequence=1\&isAllowed=y

Cabello et al., 2018 - Cabello, P., Claro, M., Lazcano, D., Antezana, L. (2018). La inclusión digital de niños y adolescentes chilenos desde la perspectiva de usos y habilidades. In Jiménez E. et al. (eds.) Entre Selfies y Whatsapps. Oportunidades y riesgos para la infancia y la adolescencia conectada. Madrid: Gedisa: 259-278.

Cabello et al., 2020 - Cabello, P., Claro, M., Rojas, R., Trucco, D. (2020). Children's and adolescents' digital access in Chile: The role of digital access modalities in digital uses and skills. Journal of Children and Media: 1-19. DOI: https://doi.org/10.1080/17482798.2020.1744176

Chassiakos et al., 2016 - Chassiakos, Y. L., Radesky, J., Christakis, D., Moreno, M. A., Cross, C. (2016). Children and adolescents and digital media. Pediatrics. 138(5): e20162593. DOI: https://doi.org/10.1542/peds.2016-2593

Condeza et al., 2019 - Condeza, R., Herrada-Hidalgo, N., Barros-Friz, C. (2019). New parental mediation roles: Parents' perceptions of their children's relationship with multiple screens. Profesional de la Información. 28(4): e280402. DOI: https://doi.org/10.3145/epi.2019.jul.o2

Ferrari, 2013 - Ferrari, A. (2013). DIGCOMP: A framework for developing and understanding digital competence in Europe. (Report EUR26035). Joint Research Centre of the European Commission. DOI: https://doi.org/10.2788/52966

Garmendia et al., 2019 - Garmendia, M., Jiménez, E., Karrera, I, Larrañaga, N., Casado, M.A, Martínez, G., Garitaonandia, C. (2019). Actividades, Mediación, Oportunidades y Riesgos online de los menores en la era de la convergencia mediática. EU Kids Online/Incibe. [Electronic resource]. URL: https://addi.ehu.es/handle/10810/49632

Haddon et al., 2020 - Haddon, L., Cino, D., Doyle, M., Livingstone, S., Mascheroni, G., Stoilova, M. (2020). Children's and young people's digital skills: a systematic evidence review. (2nd version). KU Leuven, Leuven: ySKILLS. DOI: http://doi.org/10.5281/zenodo.4274654

Haddon, 2018 - Haddon, L. (2018). Domestication and social constraints on ICT use: Children's engagement with smartphones. In Vincent, J., Haddon, L. (eds.), Smartphone Cultures. London: Routledge: 71-82.

Helsper et al., 2021 - Helsper, E.J., Schneider, L.S., van Deursen, A.J.A.M., van Laar, E. (2021). The youth Digital Skills Indicator. (Versión 1). KU Leuven, Leuven: ySKILLS.

Jiménez-Morales et al., 2020 - Jiménez-Morales, M., Montaña, M., Medina-Bravo, P. (2020). Childhood use of mobile devices: Influence of mothers' socio-educational level. Comunicar. 64: 21-28. DOI: https://doi.org/10.3916/C64-2020-02

Livingstone et al., 2017 - Livingstone, S., Ólafsson, K., Helsper, E.J., Lupiáñez- Villanueva, F., Veltri, G.A., Folkvord, F. (2017). Maximizing opportunities and minimizing risks for children online: The role of digital skills in emerging strategies of parental mediation. Journal of Communication. 67(1): 82-105. DOI: https://doi.org/10.1111/jcom.12277 
Livingstone et al., 2018 - Livingstone, S., Mascheroni, G., Staksrud, E. (2018). European research on children's internet use: Assessing the past and anticipating the future. New Media \& Society. 20(3): 1103-1122. DOI: https://doi.org/10.1177/1461444816685930

Livingstone et al., 2019 - Livingstone, S., Kardefelt-Winther, D., Kanchev, P., Cabello, P., Claro, M., Burton, P., Phyfer, J. (2019). Is there a Ladder of Children's Online Participation?: Findings from Three Global Kids Online Countries. (Innocenti Research Briefs, 2019-02). UNICEF/Office of Research. [Electronic resource]. URL: https://www.unicef-irc.org/publications/ 1019-ladder-of-childrens-online-participation-findings-from-three-gko-countries.html

Livingstone, Helsper, 2010 - Livingstone, S., Helsper, E. (2010). Balancing opportunities and risks in teenagers' use of the internet: The role of online skills and internet self-efficacy. New Media \& Society. 12(2): 309-329. DOI: https://doi.org/10.1177/1461444809342697

Martínez et al., 2020 - Martínez, G., Casado, M. A., Garitaonandia, C. (2020). Online parental mediation strategies in family contexts of Spain. Comunicar. 65: 67-76. DOI: https://doi.org/10.3916/C65-2020-06

Mascheroni et al., 2016 - Mascheroni, G., Livingstone, S., Dreier, M., Chaudron, S. (2016). Learning versus play or learning through play? How parents'imaginaries, discourses and practices around ICTs shape children's (digital) literacy practices. Media Education. 7(2): 242-261. DOI: https://doi.org/10.14605/MED721606

Mascheroni et al., 2020 - Mascheroni, G., Cino, D., Mikuška, J., Lacko, D., Smahel, D. (2020). Digital skills, risks and wellbeing among European children: Report on (f) actors that explain online acquisition, cognitive, physical, psychological and social wellbeing, and the online resilience of children and young people. ( $3^{\text {rd }}$ version). KU Leuven, Leuven: ySKILLS. DOI: http://doi.org/10.5281/zenodo.4313274

Mascheroni, Ólafsson, 2014 - Mascheroni, G., Ólafsson, K. (2014). Net Children Go Mobile: risks and opportunities. Second Edition. Milano: Educatt. [Electronic resource]. URL: http://eprints.lse.ac.uk/56986/1/_lse.ac.uk_storage_LIBRARY_Secondary_libfile_shared_repo sitory_Content_Net\%20Children\%20Go\%20Mobile\%20Project_Reports_Net\%20children\%20go \%20mobile\%2orisks\%20and\%20opportunities\%20(2nd\%20ed.).pdf

Orben, Przybylski, 2019 - Orben, A., Przybylski, A.K. (2019). The association between adolescent well-being and digital technology use. Nature Human Behaviour. 3: 173-182. DOI: https://doi.org/10.1038/s41562-018-0506-1

Rodríguez-de-Dios et al., 2018-Rodríguez-de-Dios, I., van Oosten, J.M., Igartua, J.J. (2018). A study of the relationship between parental mediation and adolescents' digital skills, online risks and online opportunities. Computers in Human Behavior. 82: 186-198. DOI: https://doi.org/10.1016/j.chb.2018.01.012

Smahel et al., 2020 - Smahel, D., Machackova, H., Mascheroni, G., Dedkova, L., Staksrud, E., Ólafsson, K., Livingstone, S., Hasebrink, U. (2020). EU Kids Online 2020: Survey results from 19 countries. EU Kids Online. https://doi.org/10.21953/lse.47fdeqjo1ofo

Subtel, 2017 - SUBTEL. (2017). IX Encuesta de Acceso y Usos de Internet. Subsecretaría de Telecomunicaciones de Chile. [Electronic resource]. URL: https://www.subtel.gob.cl/wp-content/ uploads/2018/o7/Informe_Final_IX_Encuesta_Acceso_y_Usos_Internet_2017.pdf

Trucco, Palma, 2020 - Trucco, D., Palma, A. (2020). Infancia y Adolescencia en la era digital: un informe comparativo de los estudios de Kids Online del Brasil, Chile, Costa Rica y el Uruguay, Documentos de Proyectos. (LC/TS.2020/18/REV.1). Comisión Económica para América Latina y el Caribe (CEPAL). [Electronic resource]. URL: https://www.cepal.org/ es/publicaciones/ 45212-infancia-adolescencia-la-era-digital-un-informe-comparativo-estudios-kids-online

Van Deursen et al., 2016 - Van Deursen, J.A.M. A., Helsper, E.J., Eynon, R. (2016). Development and validation of the Internet Skills Scale (ISS). Information, Communication \& Society. 19(6): 804-823. DOI: https://doi.org/10.1080/1369118X.2015.1078834 